\begin{tabular}{|c|c|}
\hline \multirow{3}{*}{ 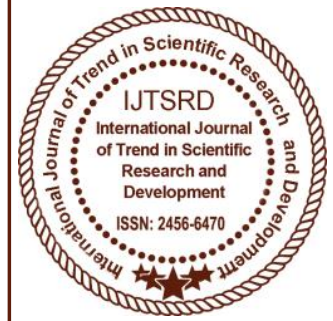 } & $\begin{array}{l}\text { International Journal of Trend in Scientific } \\
\text { Research and Development (IJTSRD) }\end{array}$ \\
\hline & UGC Approved International Open Access Journal \\
\hline & ISSN No: 2456 - 6470 | www.ijtsrd.com | Volume - 1 | Issue - 5 \\
\hline
\end{tabular}

\title{
Asset Allocation as Determinant of Bank Profitability in Nigeria
}

Gloria Obiageli IZUNDU

Department of Banking and Finance, NnamdiAzikiwe University, Anambra State, Nigeria

\section{Cyprian Okey OKORO}

Department of in Banking and Finance, Chukwuemeka Odumegwu Ojukwu University, Anambra State, Nigeria

\section{Clem NWAKOBY}

Assoc. Prof , Department of Banking and Finance, NnamdiAzikiwe University, Anambra State, Nigeria

Udoka Bernard ALAJEKWU*

Department of Banking and Finance, NnamdiAzikiwe University, Anambra State, Nigeria

\section{ABSTRACT}

In the business of banking, banks do not only invest the received deposits to meet future obligations but also to make a profit. The study investigates the effect of asset allocation on profitability Deposit Money Banks in Nigeria. The study adopted a panel regression model involving five selected commercial banks. The data were obtained from the financial statement and annual reports of the selected banks spanning 2011 to 2015 . The explanatory variables of the study are liquid assets, equities, loans, securities. The panel Ordinary Least Square regression was employed for data analyses. The findings have shown that aggregate asset allocation variable significantly explains 54\% of changes in bank profits. Further results shows that liquid assets, investments equities have positive but insignificant effect on profitability of Deposit Money Banks in Nigeria; loan extension of the banks have insignificant negative effect on profitability of Deposit Money Banks in Nigeria; whereas investments in security have significant positive effect on the profitability of Deposit Money Banks in Nigeria. The study thus concluded that asset allocation is an important financial management tool to enhancing bank profitability, and that investments in securities are veritable channel for banks to improve profitability in Nigeria.
Keywords: Asset allocation, firm profitability, Deposit Money Banks, Nigeria

\section{INTRODUCTION}

Combining the challenges of matching liabilities with assets and then staying within the regulatory framework will have little or no impact, if it is not measured to performance. For banks in Nigeria to remain competitive they must make, at least an optimal profit from all assets held. Thus, in order to increase wealth and meet obligations, banks need to create a portfolio that will fulfil their needs. The creation of an optimal portfolio includes asset allocation, which is the selection among different main asset classes (Sharpe, 1992) such as bonds and stocks.

A portfolio's total return can be decomposed into three components: (1) the market return, (2) the asset allocation policy return in excess of the market return, and (3) the return from active portfolio management (Bailey, Richards, and Tierney 2007; Solnik and McLeavey 2003). The "total return" of the portfolio or fund is the return net of all expenses and fees. The measure of the "market return" is the weighted return for a given period for all the funds in the applicable universe. The "asset allocation policy return" refers to 
the static asset allocation return of the fund; intuitively, the asset allocation policy return in excess of the market returns are them static asset allocation return less the market return. The "active portfolio management return" refers to the remaining returns from security selection, tactical asset allocation, and fees.

Asset allocation relies on the notion; that different asset classes offer returns that are not perfectly correlated and diversifying portfolios across asset classes will help to optimize risk-adjusted returns (Larrabee, 2012). The goal of asset allocation is to achieve the best possible expected return and risk profile (Dahlquist\& Harvey, 2001).Asset allocation policy is the formation of asset class weights (Brinson, Singer \&Beebower, 1991), and returns from asset allocation policy are regarded as the passive return on investment (Ibbotson, 2010). The procedure of managing the portfolios weights in relation to the normal distribution among classes is defined as active asset allocation (Brinson, Singer \&Beebower, 1991). Active asset allocation includes market timing and security selection and is more related to skills and knowledge of investment managers (Andonov\& Bauer Cremers, 2012). As the three elements, asset allocation policy, market timing and security selection, have been pointed out as the main factors of performance in portfolio management (Beath, 2014), it could be questioned why asset allocation policy is often overlooked by researchers in favour of active asset allocation (Andonov, Bauer \&Cremers, 2012). To address this question forms the fulcrum of this study.

The essential part of asset allocation is to optimise the trade-off between risk and return of the portfolio (Bodie, Kane \& Marcus, 2011). Banks do not only invest the received deposits to meet future obligations but also to make a profit. Studies that claim that asset allocation is one important investment strategy to boost firm profit are abound but only exist in foreign economies. This study is an attempt to replicate in Nigeria, the argument that asset allocation has effect on profit of banks.

\section{REVIEW OF RELATED LITERATURE}

\subsection{Conceptual Framework}

\subsubsection{Asset Allocation}

The construction of a portfolio between different asset classes is what represents assetallocation (Bodie, Kane \& Marcus, 2011). Mirae Asset Knowledge Academy (2016) defines asset allocation as combining asset classes such as equities, bonds and cash in varying proportions within one customized, diversified investment portfolio.However, portfolio diversification is the mix of stock, bonds and cash held in a portfolio (Fidelity Investment, 2015). The creation of an investment portfolio can be seen as a top-down process which startswith the capital allocation meaning the decision how much should be invested in therisky portfolio and the risk-free assets, and goes over to the question how to composethe risky portfolio.

However, the construction of the risky portfolio is the concern of assetallocation which is about making a choice between the asset classes like stocks, bonds,real estate or commodities under the assumption of neutral capital market conditionswhich means that no asset class is underpriced or overpriced (proportional risk-returnexpectations) (Bodie, Kane \& Marcus, 2014; Hensel, Ezra \&Ilkiw, 1991). Theestablishment of the broad asset classes (asset allocation policy) decides about theexposure of the portfolio to market risk (beta), while the selection of particular securitieswithin the chosen asset classes (security selection) makes the decision about the alphaexposure (Idzorek\&Kowara, 2013).

There are three levels of asset allocation including benchmarking, Strategic asset allocation, and tactical asset allocation (Dahlquist\& Harvey, 2001). The benchmark asset allocation is a program that exactly replicate the investment weights of the benchmark index. This type of asset allocation is sometimes referred to as indexing wherein no information is used other than the usual details of indexing: determining market weights, and managing delisting, new listing, buyback, secondary market offerings, dividends and warrants. The second level of asset allocation is the strategic allocation which is a longterm in nature with at least five years horizon. In this asset allocation level, managers set bets on the performance of asset classes based on future forecasts. The five year plan is usually allowed to run to end and need for yearly updates and rebalancing of investment plans. The deviations that arise from benchmarks introduces a tracking error. This is a standard deviation of the differences between the benchmark returns and portfolio returns and this is called the 
strategic tracking error (Dahlquist\& Harvey, 2001). Then in the third level of asset allocation being the tactical asset allocation, the investment managers will take short term bets usually monthly or quarterly and deviate from the strategic weights. The difference between the strategic and tactical weights induces a tactical tracking error. However, the difference between benchmark weights and tactical weights is the total tracking error.

Mirae Asset Knowledge Academy (2016) noted that the benefits of Asset Allocation includes reduced risk, improved chances of more consistent earnings, and helping in achieving a focused investment goals. The study explained that portfolio diversification may reduce the amount of volatility experienced when market risk are spread across many different asset classes. In explaining further how asset allocation reduces risk, it noted that by including asset categories with investment returns that move up and down under different market conditions within a portfolio, an investor can protect against significant losses. Again, it explained that how asset allocation improves chances of more consistent earning is that investing in several asset classes improve the chances of participating in performing asset classes and lessen the impact of poor performing asset categories on your overall portfolio returns. An investor will improve quality of investment with a combination of asset class that carries a different potential of risk and growth; for instance, high-risk investments such as equities which offer the highest possible returns and a fixed deposits that come with relatively lower risk and give stable returns. To know how asset allocation helps investors to stay focused on goals, it noted that a well-planned asset allocation portfolio alleviates the need to constantly adjust investment positions based on market trends. Inclusion of enough risk in a portfolio enables investments to earn a large enough return to meet goal.

Having explained all the three levels of asset allocation, it is worthy of noted that the strategic asset allocation is the long-run allocation of funds across asset classes (Blake, Lehmann \&Timmermann, 1998). This is the level of asset allocation most studied in literature. It is this level of asset allocation that allows firms to project at least five year time frame of asset allocation plan, that this study tend to use to understand the effect of asset allocation on the profitability of firms.

\subsubsection{Asset Classes}

When conducting studies on asset allocation aprimary step is to define asset classes (Sharp, 1992). The assets are assigned to classes according to some fundamental economic characteristics they have in common, which distinguishes them from asset in other classes (Greer, 1997). Thus assets are distinguished at the broadest level in three 'superclasses': capital assets, consumable/transformable assets ( $\mathrm{C} / \mathrm{T}$ assets) and store of value assets (SOV assets). Capital assets provide an ongoing source of something of value like the expectation of a stream of dividends (equities) or interest payment and residual return of principal (bonds) or net operating income and residual return (real estate). The value of capital assets changes in opposite direction of investor's discount rate if valuing them is based on the net present value of its expected returns, which economically characterises this super-class (Greer, 1997). C/T assets are physical commodities such as grain, energy products or metal, which are so named because they are consumable and transformable into other assets. Since they do not generate income, they cannot be valued using net present value analysis. Thus particular supply and demand factors are used to value them, which is the economic characteristic of this super class. In contrast to the others, SOV assets can neither be consumed nor yield an ongoing stream of value, but rather a store of value as fine art or currency. However, the lines between the super asset classes can be blurred since the economical characteristics can be overlapping for some assets like gold or real estate investment trust (REIT) shares (Greer, 1997). Nevertheless, either the correlations of the asset classes should be low, or their standard deviation should differ in case of high correlations (Sharpe, 1992; Greer, 1997).

In addition to economic factors, financial assets as claims to the income generated by real assets can be differentiated according to their risk-return characteristics and their legal or regulatory structure (Wilcox \&Fabozzi, 2013). Thus investments are commonly distinguished in three broad types: fixed income, equity and alternatives (Bodie, Kane \& Marcus, 2014; Kitces, 2012). Fixed income and equity differ mainly in their investment performance in relation to the issuer. While equity represents ownership and thus is tied directly to the success of the issuer and its real assets; fixed income or debt securities are far less risky to the financial condition 
of the issuer since they promise only a stream of fixed amount or a stream of payments determined by formula (Bodie, Kane \& Marcus, 2014). Fixed income is differentiated further in accordance to the segmentation of financial markets (money market and capital market). Money market instruments, also called cash equivalent, are short-term and highly marketable debt securities with generally low-risk like Treasury bills. In contrast fixed income securities traded on capital markets such as bonds not only have longer maturities but also contain more default risk (Bodie, Kane \& Marcus, 2014). Equity tends to be even riskier due to its residual claim and limited liability feature (Bodie, Kane \& Marcus, 2014).

\subsubsection{Profitability}

Profitability is one of the measured of financial performance of banks. Four useful measures of profitability are the rate of return on assets (ROA), the rate of return on equity (ROE), operating profit margin and net income (Hansen \&Mowen, 2005). These are regarded as market-based indicators of financial performance that captures company's internal efficiency (Orlitzky, Schmidt \&Rynes, 2003). However, since the study aims to capture asset allocation, the proportion of net profit to total assets measures of return on assets (ROA) is used in this study to measure profitability.

\subsection{Theoretical Framework}

The theoretical framework is anchored on Modern Portfolio Theory or Efficient Market Hypothesis. In the 1950s Harry Markowitz and Arthur D. Roy introduced the mean-variancecriterion to balance risk and return of portfolios and thus created the crux of ModernPortfolio Theory (MPT) (Idzorek\&Kowara, 2013). Although the two approaches differ only slightly in their liberty of investments and their choice of efficient portfolio (Markowitz, 1999), the model of Markowitz is explained and evaluated below as it is far more common (Levy and Levy, 2014). Markowitz's theory assumes that “(1) the expected return on the portfolio is theweighted average of the expected returns on individual securities and (2) the varianceof returns on the portfolio is a particular function of the variance of, and the covariancebetween, securities and their weights in the portfolio" (Markowitz, 1952, p. 5). These assumptions are based on idea that investors are risk averse and care only about the risk-return trade-off of one period portfolio (Elbanna, 2015; Fama and French, 2004). The theory showed that the portfolio variance merely measures the systematic or nondiversifiable risk as the non-systematic or diversifiable risk vanishes with increasing diversification (Marshall, 2014). Thus, distributing funds to the various asset classes is enough to improve profit of firms.

The second theory being the Efficient Market Hypothesis (EMH) is built on the idea that all available information are always 'fully' reflected in the capital market prices (Fama, 1970), which in particular gained traction since the 'theory of random walk' was rediscovered in the late 1950's and early 1960's (Jensen, 1978). According to the logic of random walk hypothesis, price changes are unpredictable and random for the unimpeded flow of information. In other words, prices vary randomly without relation to their previous values, meaning that the tomorrow price is independent from today's price and reflects only tomorrow's information (Malkiel, 2003). This supposes that financial managers do not have to border about the market risk while making asset allocation decision since all the information that will alter prices are reflected and no single participant can take undue advantage to make excess profit.l

\subsection{Empirical Studies}

A good number of the studies on asset allocation issues are qualitative in nature. In the work of Bendrich and Bergström (2015), they examined the impact of asset allocation oninsurance companies' performance within the European Economic Area (EEA) and Switzerland, where performance is measured as the return on investment (ROI). The study anchors in Modern Portfolio Theory or Efficient Market Hypothesis. Census method of sampling was adopted to select 42 firms within a timeframe of 11 years from the population of listed insurance companies. Data regarding insurer's asset class weights in debt securities, equity, real estate, derivatives, cash and equivalent, loans and receivables and the category of others were collected. The return on investment was also collected for each year of the time period and for each insurance company. Benchmarks were constructed in order to replicate what the return of a passive investment of the same proportion would have yielded. The result was inconclusive as it was not possible to determine if asset allocation policy or active management has the 
greatest impact on the return on investment. This is contradicting previous research of asset allocation and performance as researchers have found that asset allocation policy explains most or all of the return.

Xiong, Ibbotson, Idzorek and Chen (2010) examined the relative importance of asset allocation policy versus active portfolio management in explaining variability in performance. Three portfolio peer groups from theMorningstar U.S. mutual fund database: U.S.equity funds, balanced funds, and international equity funds were used in the study. The study used 10 years of return data (May 1999 - April 2009). Thereafter, the study removed duplicate share classes and required that each fund has at least five years of return data, and arrived at final sample of 4,641 U.S. equity funds, 587 balanced funds, and 400 international equity funds. The study aimed to clear the considerable confusion surrounding both timeseries and cross-sectional regressions and the importance of asset allocation. Findings are: First, by decomposing a portfolio's total return into its three components (1) the market return, (2) the asset allocation policy return in excess of the market return, and (3) the return from active portfolio management, the study found that market return dominates the other two return components. Taken together, market return and asset allocation policy return in excess of market return dominate active portfolio management. This finding confirms the widely held belief that market return and asset allocation policy return in excess of market return are collectively the dominant determinant of total return variations, but it clarifies the contribution of each.

According to Mirae Asset Knowledge Academy (2016), investors are often surprised to learn that a significant percentage of the volatility of investment performance is driven by asset allocation decisions, while other factors such as market timing and security selection have a relatively small impact on long-term investment results. The result of the analysis presented in a pie chart showed that asset allocation accounted for $91.5 \%$ while security selection (4.6\%), market timing (1.8\%) and others factors (2.1\%) accounted for drivers of investment results (performance).

Raddatz, Schmukler and Williams (2015) examined the different channels through which well-known benchmark indexes impact asset allocations, capital flows, and asset prices across countries, using unique monthly microlevel data of benchmark compositions and mutual fund investments during 1996-2014. The Benchmarks are used for identification of the effects on equity and bond mutual fund portfolios, including both passive and active funds, after controlling for industry, macroeconomic, and country-specific timevarying effects. The findings show that reverse causality and common shocks do not drive the results. Exogenous, pre-announced changes in benchmarks result in movements in asset allocations and capital flows mostly when these changes are implemented. Again, assets in the benchmarks experience abnormal returns when benchmark changes become effective, suggesting that the reallocations implied by those changes are not immediately arbitraged away. This indicates that asset allocation has effect on performance of firms.

Blake, Lehmann and Timmermann (1998) examined the performance of managed portfolios across multiple asset classes. The study employed a data of monthly observations of 306 UK pension funds from 1986 - 1994. It employed a simple decomposition to help identify the factors causing portfolio weights to change. The study found evidence of slow mean reversion in the funds' portfolio weights towards a common, time-varying strategic asset allocation. It also found that strategic asset allocation accounts for most of the time-series variations in portfolio returns, while market timing and asset selection appear to have been far less important.

Ervin, Faulk and Smolira (2009) used Monte Carlo simulation to evaluate the ability of various deposit percentages and asset allocation weights to support withdrawals in retirement that permit smoothed income over the life of an individual. The study employed returns from 1926 through 2008, to construct 10,000 return series. The asset classes considered are U.S. large capitalization stocks and U.S. long-term corporate bonds. Using the AndersonDarling test for normality, and Student's $t$ distribution to measure stock returns and bond returns; the results indicate that, in general, individuals need to deposit at least 15 percent of pre-retirement salary for 30 or more years in a portfolio consisting of at least 50 percent equity to achieve a high success rate for portfolio withdrawals. When Social Security payments are excluded from the retirement income, the success rate is greatly impacted by the savings rate, the savings period, and the amount of equity investment in the portfolio. 
Beath (2014) analyzed the net return performance of U.S. DB pension funds for the period spanning 19982011 by standardizing the time series of net returns. The results show that the excess returns from publicly traded equity REITs when compared with real estate investments in private markets over the sample period was 370 basis points (316 basis points compounded), but came with 22 percent more volatility. Furthermore, after standardization of the private real estate net return series for reporting lag and appraisal smoothing, the net returns from the two aggregate asset classes are seen to have been highly correlated. The use of leverage by listed equity REITs likely accounts in part for the fact that REITs were the best performing aggregate asset class from among all 12 aggregate asset classes included in the analysis and that REITs significantly outperformed private real estate over the sample period. However, the returns reported for private real estate investments typically also incorporate the use of some amount of leverage, and differences in the use of leverage are unlikely to explain all of the outperformance by REITs. In terms of fund performance, our study demonstrates that large U.S. corporate sector DB pension funds significantly outperformed the all fund average in terms of physical asset only net returns. The cause of the outperformance was a dramatic and timely move which saw a reduction in asset allocation to large cap U.S. stocks and an increase in asset allocation to long duration bonds circa 2007. This indicate that asset allocation brings about superior performance.

\subsection{Summary of Related Literature}

The review of literatures has shown that asset allocation is the proportion of funds invested in each asset class, while profitability of the earnings of firms can be measured as a ratio of profit after tax to asset (ROA), to equity (ROE) or operating profit margin and net income. However, the present study adopted ROA for the study. The review of empirical literature showed that asset allocation is a determinant of firm profitability. However, none of the studies so reviewed belong to Africa or even Nigeria. Also, among the studies, none tended to investigate the distribution of bank assets and its effect on profits. Hence, this study is novel and unique because it brings the application of asset allocation strategies to Nigerian firms and the banking industry in particular.

\section{METHODOLOGY}

An expost facto research design was adopted to investigate the effect of asset allocation on bank profitability in Nigeria. The population of this study comprises all the banks quoted at the Nigerian Stock Exchange (NSE) for the period of five (5) years from 2011 to 2015. However, a sample of five banks involving Access bank, UBA, Zenith, Diamond banks and Union bank was used for the study.

The study adopted the capital assets classification which groups assets into expectation of a steam of dividends (equities), interest payment and residual return of principal (bonds) and net operating income and residual return (real estate). However, the freerisk assets, and residual returns are included separately in order to account for the cost of funds used to cushion liquidity problems in banks.

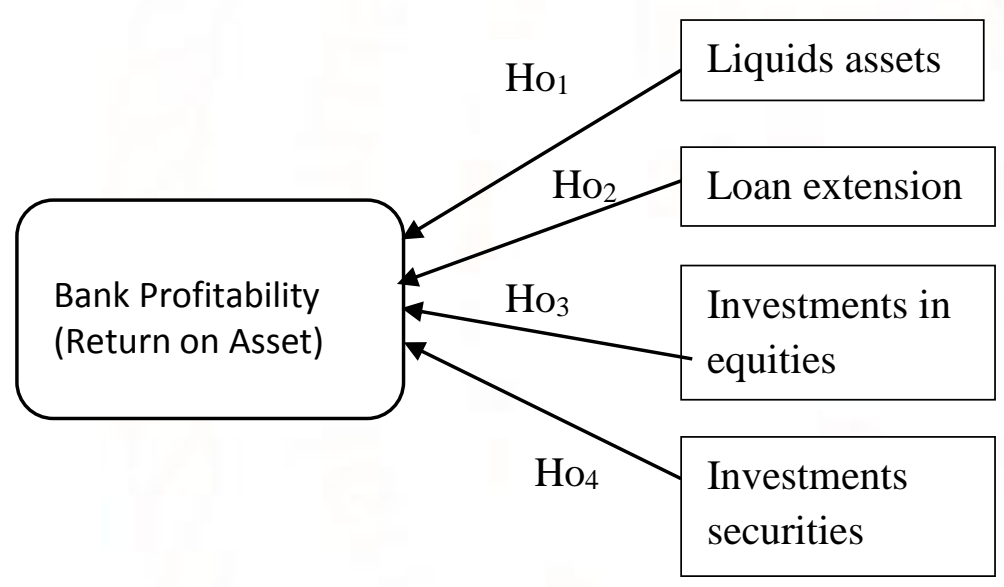

ROA = f(LIQUID, LOAN, EQUITY, SECURITY $).$

ROA $=\alpha_{0}+\beta_{1}$ LQUID $+\beta_{2}$ LOAN $+\beta_{3}$ EQUITY + $\beta_{4}$ SECURITY $+\mu$

Where:

$\mathrm{ROA}=$ Return on asset as a measure for bank profitability and the dependent variable of the model.

LIQUID = Proportion of cash equivalent (liquid) assets including real cash and assets that can easily be converted to cash within a short time frame such as cash and balances with banks, treasury bills, due from other banks and derivatives.

LOAN = Proportion of assets held invested in long term fixed income assets including bank loans to 
government and firms, federal government and industrial bonds as well as loans to other banks.

EQUITY $=$ Proportion of equity capital comprising all funds invested in dividend yielding assets including investment in subsidiaries, investment in associates.

SECURITIES $=$ proportion of assets in investment securities

$\alpha_{0}=$ constant, $\beta_{1}, \beta_{2}, \beta_{3}$ and $\beta_{4}$ are the coefficients of the explanatory variables of working capital management. $\mu$ is the error term.
Descriptive statistics and inferential statistical techniques were used to analyze the data. Multivariate regression Model based on Cross sectional pooled data from the annual reports and other financial statements. Pooled panel data analysis, also called the constant coefficients model is one where both intercepts and slopes are constant, where the cross section firm data and time series data are pooled together in a single column assuming that there is no significant cross section or temporal effects (Gujarati, 2003).

\section{RESULTS}

\section{Description of the variables}

Table 1: Descriptive Statistics

\begin{tabular}{|l|c|c|c|c|c|}
\hline & ROA & LIQUID & LOAN & EQUITY & SECURITY \\
\hline Mean & 0.01 & 0.21 & 2.62 & 0.60 & 10.67 \\
\hline Maximum & 0.04 & 0.40 & 7.66 & 2.73 & 23.13 \\
\hline Minimum & -0.09 & 0.06 & 0.93 & 0.17 & 1.58 \\
\hline Std. Dev. & 0.03 & 0.10 & 1.81 & 0.54 & 5.82 \\
\hline & & & & & \\
\hline Jarque-Bera & 121.76 & 1.03 & 7.81 & 95.19 & 1.73 \\
\hline Probability & 0.0000 & 0.5987 & 0.0202 & 0.0000 & 0.4220 \\
\hline & & & & & \\
\hline Observations & 25 & 25 & 25 & 25 & 25 \\
\hline
\end{tabular}

The results of the descriptive statistics show that mean and standard deviation which measures the average values of the variables and their degree of variation. The minimum and maximum shows the highest and lowest values of the variables. The result of the mean for ROA indicated that about an average of $1 \%$ profit after tax is attributable to a unit of assets of the banks selected for the study. The highest earning of the banks was $4 \%$ (see Maximum). This indicates that most of the variables do not have outlier. However the Jarque-Bera (JB) statistics of the variables and their corresponding probabilities test for the normality of the time series. From the results of JB, only LIQUID and SECURITY have p.values above 0.05 level of significance. Thus, only liquid assets and investment securities are normally distributed while others (LOAN, and EQUITY) are not normally distributed.

\section{Table 2: Result of Panel OLS regression technique}

\section{Sample: 20112015}

\section{Periods included: 5}

Cross-sections included: 5

Total panel (balanced) observations: 25 
International Journal of Trend in Scientific Research and Development (IJTSRD) ISSN: 2456-6470

\begin{tabular}{|c|c|c|c|c|}
\hline LIQUID & 0.092769 & 0.104898 & 0.884376 & 0.3882 \\
\hline LOAN & -0.002464 & 0.005244 & -0.469802 & 0.6441 \\
\hline EQUITY & 0.005323 & 0.010562 & 0.504005 & 0.6204 \\
\hline SECURITY & 0.002544 & 0.001236 & 2.057486 & 0.0244 \\
\hline C & -0.008990 & 0.048243 & -0.186355 & 0.8543 \\
\hline R-squared & 0.535581 & & \\
\cline { 1 - 1 } Adjusted R-squared & 0.380775 & \multicolumn{2}{|c}{ Durbin-Watson stat } & 1.777093 \\
\hline F-statistic & 3.459688 & & \\
\hline Prob(F-statistic) & 0.018823 & & & \\
\hline
\end{tabular}

Dependent Variable: ROA; *significant at 1\%, $* *$ significant at 5\%

The result of the regression analyses showed that the coefficient of determination $\left(\mathrm{R}^{2}\right)$ is 53.56. This indicates that about $54 \%$ of changes in bank profit can be explained by asset allocation variables included in this study. This implies that asset allocation can explain 54\% of bank profitability in Nigeria. This suggests that asset allocation is an important financial management tool to enhancing bank profitability.

The result of the F-statistics tests the level of significance of the independent variables on the dependent variable. The result is 3.4596 with probability of 0.0188 which is less than 0.05 . Since the computed p.value is less than 0.05 , we conclude that asset allocation has significant effect on bank profitability in Nigeria. The Durbin-Watson (DW) statistics test whether there is autocorrelation in the model. Absence of autocorrelation means that the model is reliable. Since the DW of 1.777 is approximately equal to 2 , we conclude that the mode is reliable.

To address the specific objectives of the study, the coefficient of regression answered the research questions while the corresponding t-test tested the hypotheses.

\section{Effect of liquid assets of banks on the profitability}

The coefficient of regression of LIQUID is 0.0928 which indicate that liquid assets have positive effect on profitability. This implies that a unit increase in bank liquid asset brings about $9 \%$ increases in bank profit. The hypotheses that "Liquids assets of banks have no significant effect on the profitability of Deposit Money Banks in Nigeria" is tested using the $\mathrm{t}$-statistics. The t-value is 0.8843 with probability value of 0.3882 . Since the p.value is greater than 0.05 , we cannot reject the null hypothesis. Thus we conclude that liquids assets of banks have no
Significant effect on the profitability of Deposit Money Banks in Nigeria.

\section{Effect of loan extension of banks on the profitability}

The result of the coefficient of regression for LOAN is -0.0024 . This indicates that loan extension of the banks have negative effect on profitability. This shows that a unit increase in the amount of loan grants will brings about $0.2 \%$ decrease in bank profit. This implies that bank profits from loan grants increases at a decreasing rate over the period of this study. The $t-$ statistics has a value of -.4698 with probability of 0.6441 . The p.value is above 0.05 , thus we accepted the null hypothesis that "Loan extension of banks have no significant effect on the profitability of Deposit Money Banks in Nigeria”.

\section{Effect of investments in equities on the profitability}

The coefficient of regression of EQUITY is 0.0053 which indicate that equity investments have positive effect on profitability. This implies that a unit increase in bank equity investment brings about $0.5 \%$ increase in bank profit. The hypotheses that "Investments in equities have no significant effect on the profitability of Deposit Money Banks in Nigeria" are tested using the t-statistics. The t-value is 0.5040 with probability value of 0.6204 . Since the p.value is greater than 0.05 , we cannot reject the null hypothesis. Thus we conclude that investments in equities have no significant effect on the profitability of Deposit Money Banks in Nigeria.

\section{Effect of investments in securities on the profitability}


The coefficient of regression of SECURITY is 0.0025 which indicate that investment securities have positive effect on profitability. This implies that a unit increase in bank investment security brings about $0.3 \%$ increase in bank profit. The hypotheses that "Investments in security have no significant effect on the profitability of Deposit Money Banks in Nigeria" is tested using the t-statistics. The t-value is 2.0574 with probability value of 0.0244 . Since the p.value is less than 0.05 , we reject the null hypothesis. Thus we conclude that investments in security have significant effect on the profitability of Deposit Money Banks in Nigeria.

\section{CONCLUSION AND RECOMMENDATIONS}

The study have investigated the effect of Deposit Money Banks' asset allocation on profitability using panel data from five commercial banks from 2011 to 2015. The findings have shown that aggregate asset allocation variable significantly explains $54 \%$ of changes in bank profits. The study thus posit that asset allocation is an important financial management tool to enhancing bank profitability. However, the results of the explanatory variables showed that assets allocated at loan grants can brings about negative effect on bank profits. The result of investments in securities indicated a significant positive effect, which implies that securities are veritable investment channel for banks to improve profitability in Nigeria.

Based on the findings, the study recommended that:

1. Banks in Nigeria should enhance the use of securities investment as option for cushioning asset risks.

2. Also, the study suggests that the regulatory authorities should monitor loan grants process in Nigeria since it is expected that loans should contributed positively to bank profit. A case where bank could be enhance profit through loan grant connotes bad loan management.

\section{REFERENCES}

1) Andonov, A., Bauer, R., and Cremers, M. (2012). Can Large Pension Funds Beat the Market? Asset Allocation, Market Timing, Security Selection and the Limits of Liquidity. Retrieved from http://www.efa2012.org/papers/t3h2.pdf.

2) Bailey, J. V., Richards, T. M. \& Tierney, D. E. (2007). "Evaluating Portfolio Performance." In
Managing Investment Portfolios: A Dynamic Process. 3rd ed. Edited by John L. Maginn, Donald L. Tuttle, Dennis W. McLeavey, and Jerald E. Pinto. Hoboken, NJ: John Wiley \& Sons.

3) Beath, A. (2014). Asset allocation and fund performance of defined benefit pensionfunds in the United States between 1998-2011. Retrieved fromhttps://www.reit.com/sites/default/files/pdf/A sset $\% 20$ Allocation $\% 20$ and $\% 20$ Fund $\% 20$ Performa nce $\% 20$ Merged $\% 20$ With $\% 20$ Title $\% 20$ Page $\% 20(1$ 2May2014).pdf.

4) Bendrich, D. \&Bergström, J. (2015). Impact of asset allocation on insurance companies' performance: A study of the European Economic Area. Retrieved from http://www.divaportal.se/smash/get/diva2:844037/FULLTEXT01. pdf.

5) Blake, D., Lehman, B. N., and Timmermann, A. (1999). Asset Allocation Dynamics and Pension Fund Performance. The Journal of Business, 72 (4), 429-461.

6) Bodie, Z., Kane, A., and Marcus, A. J. (2014). Investments. 10th Edition. New York: McGrawHill Education.

7) Bodie, Z., Kane, A., and Marcus, A. J., (2011). Investments and Portfolio Management. 9th Edition. New York: McGrawn-Hill Irwin.

8) Brinson, G. P., Hood, R. L., and Beebower, G. L. (1986). Determinants of portfolio performance. Financial Analyst Journal, 42 (4), 39-48.

9) Brinson, G. P., Singer, B. D., and Beebower, G. L. (1991). Determinants of portfolio performance II: An update. Financial Analyst Journal, 47 (3), 4048.

10) Dahlquist, M. \& Harvey, C. R. (2001). Global tactical asset allocation. Emerging Markets Quarterly, Spring, 6-14.

11) Elbannan, M. A. (2015). The Capital Asset Pricing Model: An Overview of the Theory. International Journal of Economics and Finance, 7 (1), 216-228.

12) Ervin, D. M., Faulk, G. K. \&Smolira, J. C. (2009). The Impact of Asset Allocation, Savings and Retirement Horizons, Savings Rates, and Social Security Income in Retirement Planning: A Monte Carlo Analysis. http://coba.belmont.edu/fac/smoliraj/incomesmoot hing.pdf.

13) Fama, E. F. (1970). Efficient Capital Markets: A Review of Theory and Empirical Work. The Journal of Finance, 25 (2), 383-417. 
14) Fama, E. F., and French, K. R. (2004). The Capital Asset Pricing Model: Theory and Evidence. The Journal of Economic Perspectives, 18 (3), 25-46.

15) Fidelity Investment (2015). Investment strategy: Interpreting key concepts and choosing appropriate strategies. Retrieved from https://www.fidelity.com/binpublic/060_www_fidelity_com/documents/ISDG. pdf.

16) Greer, R. J. (1997). What is an Asset Class, Anyway? The Journal of PortfolioManagement, 23 (2), 86-91.

17) Gujarati, N. D. (2003). Basic Econometrics. 4th Edition, Tata: McGraw-Hill Publishing.

18) Hansen, R. \&Mowen, M. (2005). Management accounting (7 Ed.). Singapore: South-Western.

19) Hensel, C. R., Ezra, D. D., and Ilkiw, J. H. (1991). The Importance of the Asset Allocation Decision. Financial Analysts Journal, 47 (4), 65-72.

20) Ibbotson, R. G., (2010). The importance of asset allocation. Financial Analysts Journal, 66 (2), 1820. Idzorek, T. M., and Kowara, M. (2013). Factor-Based Asset Allocation vs. Asset-ClassBased Asset Allocation. Financial Analysts Journal, 69 (3), 19-29.

21) Jensen, M. C. (1978). Some anomalous evidence regarding market efficiency. Journal of Financial Economics, 6 (2-3), 95-101.

22) Kitces, M. E. (2012). What Makes Something an Alternative Asset Class, Anyway? Journal of Financial Planning, 25 (9), 22-23.

23) Larrabee, D. (2012). The Truth about Asset Allocation and Active Management. Retrieved from http://seekingalpha.com/article/371631-thetruth-about-asset-allocation-and-activemanagement?page $=2$.

24) Malkiel, B. G. (2003). The Efficient Market Hypothesis and Its Critics. Journal of Economic Perspectives, 17 (1), 59-82.

25) Markowitz, H. (1952). Portfolio Selection. The Journal of Finance, 7 (1), 77-91.

26) Markowitz, H. (1999). The Early History of Portfolio Theory: 1600-1960. Financial Analyst Journal, 55 (4), 5-16.

27) Marshall, C. M. (2014). Isolating the systematic and unsystematic components of a single stock's (or portfolio's) standard deviation. Applied Economics, 47 (1), 1-11.

28) Mirae Asset Knowledge Academy (2016). Asset Allocation Strategy drives Investment Returns. Terms of the Week. Retrieved from
http://www.miraeassetmf.co.in/uploads/TermofW eek/AssetAllocationImportance.pdf.

29) Orlitzky, M., Schmidt, F. L., and Rynes, S. L. (2003). Corporate social and financialperformance: A meta-analysis. Organization studies, 24 (3), 403-441.

30) Raddatz, C., Schmukler, S. L. \& Williams, T. (2015). International asset allocations and capital flows: The benchmark effect. Retrieved from http://www.lse.ac.uk/economics/currentStudents/r esearchStudents/EDPjamboree/Williams_UPF_E DPpaper.pdf.

31) Sharpe, W. F. (1992). Asset allocation: Management style and performancemeasurement. Journal of Portfolio Management, 18 (2), 7-19.

32) Solnik, B. \&McLeavey, D. (2003). "Global PerformanceEvaluation." In International Investments. 5th ed. UpperSaddle River, NJ: Pearson Addison-Wesley.

33) Wilcox, J. W., and Fabozzi, F. J. (2013). Financial Advice and Investment Decisions: A Manifesto for Change. New Jersey: John Wiley \& Son.

34) Xiong, J. X., Ibbotson, R. G., Idzorek, T. M., and Chen, P. (2010). The equal importance of asset allocation and active management. Financial Analysts Journal, 66 (2), 22-30. 